\title{
When Juliet Turns Black: Social Scapegoating in Alice Childress's Wedding Band
}

\author{
Asmaa Mehdi Saleh* \\ College of Science for Women, University of Baghdad, Iraq \\ Corresponding Author: Asmaa Mehdi Saleh, E-mail: asmaamehdi72@gmail.com
}

\section{ARTICLE INFO}

\section{Article history}

Received: April 01, 2018

Accepted: July 09, 2018

Published: November 01, 2018

Volume: 7 Issue: 6

Advance access: September 2018

Conflicts of interest: None

Funding: None

\begin{abstract}
Since its production William Shakespeare's Romeo and Juliet has been considered too modern for its time because of its portrayal of ill-fated characters whose tragedy is not triggered by any personal flaw of their own, but by family feuds and social scapegoating. In contemporary times, the playwrights still focus on similar stories of unattainable love and tragic romantic figures, who fall prey to the familial and social pressures. In her Wedding Band (1973), Alice Childress presents her black and white Romeo and Juliet who are modern victims of the omnipresent racism in their society. The play confirms that racism is not only practised by whites against blacks but also displayed by blacks against whites. In Wedding Band, Childress presents images of angry women united by their suffering and need of sisterly solidarity. Their anger is a positive rather than negative factor as it frees the heroine from the ties that make her an outcast in her own community. This paper discusses the destiny of two lovers who face refusal from their family and society and the subsequent anger of the female characters whether in favour or against this romantic relation.
\end{abstract}

Key words: Anger, African American Women, Oppression, Women's Rights

\section{INTRODUCTION}

text In the previous years of Civil Rights Movement, black art used to express sorrow and protest against white oppression, whereas in the 50 s and 60 s of the $20^{\text {th }}$ century, the black theatre became more and more a theatre of anger, a theatre that spoke to the black audience about the way and the means that could change their situation instead of lamenting about the justice they were deprived from (Schipper,131). The most important thing, according to Alice Childress, about the drama is that it reveals the denial of women's rights by laws created by men to protect men only and because of these laws, female characters cannot live out their lives fully (Cashman, 151). Thus, in her play Wedding Band, "both her black and white female characters become victims of a patriarchal system that shuns them because of race, because of class, and because of gender"(Ibid.).

Childress's living in a female-run household during her early adolescence shaped her into the confident playwright, actress, and novelist she was to become later (Beaulieu, 165). Childress's grandmother, Eliza White, fostered the spiritual life of her granddaughter by taking her to church services and exposing her to the lives of the poorest of the poor. White, in this way, planted into Childress's consciousness the idea that human beings had duties to help one another, especially less fortunate ones. Childress found a personalized education in the arts as her grandmother made great efforts to expose the young woman to the cultural and artistic life of New York City (Ibid.).
Childress devotes herself to write authentic portrayals of American life in general. Her plays carry leftist politics that are tempered by her characters who insist on being treated as humans with dignity. Since she is a single parent and has worked to support herself and her only daughter, Jean, she knows much about African American women's troubles in work. Her many different jobs have equipped her with experience and brought her into contact with the working class people depicted in her plays (Wilkerson, 136).

\section{Star-crossed Lovers in Wedding Band Facing Racialism}

The American theater is abundant with stereotypical images of black women depicted as silent, marginalized and oppressed. In their endeavors to counterattack these traditional passive representations of female characters, $20^{\text {th }}$ century African-American women dramatists presented the black females as rebellious characters, who are able to work and assert their identity, defying their male-dominated racial community. Childress's drama portrays black female characters involved in confrontations which give new ideas about the behavior of black women and these encounters "expose the social and civil laws that call for certain modes of action" (Diggs, 30). Soyica Diggs further praises the playwright's female protagonists for their ability to "resist or question the conventions of motherhood, the implicit racial hierarchies within professional relationships, and the social protocols limiting the content of public conversations" (Ibid.). 
Childress crosses race lines in her Wedding Band, subtitled: A Love Hate Story Told in Black and White. From the play's "restrictive socio-political setting one can comprehend why it is one of Childress's most serious and tragic plays" (Jennings, 142). Based on a true story told by Childress's grandmother, Wedding Band was written during the Civil Rights movement, it offers both a realistic portrayal of the consequences of an interracial relationship at that time, and an indictment of "anti-woman" laws that forbade divorce and certain marriages in an effort to control women. Most major productions drew criticism from both white and black critics (Osborne, 571). The play condemns the maltreatment of the American system for women in general. It represents a protest towards "anti-women laws" of that time, as Nicky Cashman opines:

Childress's play acts as a protest regarding the refutation of women's rights and her intention was to create a 'vigorous political statement' against such issues. Close textual analysis of this drama will clearly illustrate how inhumane anti-woman laws endorsed patriarchal norms that made life virtually intolerable for black and white women alike. (Cashman, 149)

For centuries, star-crossed lovers were the source of pity and compassion in drama. They have been portrayed as victims of the controversies of their families. They were doomed because their families failed to tolerate and forget their disagreements. Like the traditional lovers, lovers in modern drama have been depicted as victims of both family and society. In Wedding Band, the two lovers struggle to defeat the racial boundaries that separate them as lovers and humans.

The plot of Wedding Band deals with an interracial relationship set in early $20^{\text {th }}$ century in Charleston. It is the story of Julia, a black seamstress, and Herman, a white baker, who are entangled in a long-term relationship but are prohibited by law from being married. As Herman becomes ill and is dying, Julia is forced to confront Herman's racist mother along with her black neighbors who question her relationship with Herman. By the end of the play Julia "acknowledges the weight and significance of their respective histories and what they bring to bear on their relationship" (Wedding Band, 81). Unlike Shakespeare's powerless Juliet, Julia is depicted as a defiant angry woman, who expresses her rejection against the discrimination of both white and black societies.

African-American women's troubles with their men have generated anger and, from that anger, self-reflection. Besides, the cultural and racial pressures on the black women intensify their suffering and render them in an increasing state of frustration and anger. Bonnie Daniels suggests: "We have been and are angry sometimes not for what men have done, but for what we've allowed ourselves to become, again and again in my past, in my mother's past, in my centuries of womanhood passed over, for the 'sake' of men, whose manhood we've helped undermine" (Quoted in Patricia Collins, 152). Their anger is a state of dissatisfaction that shadows all their emotions, actions, and way of thinking.

In her study of anger, Sandra Thomas asserts that anger can be caused by themes that include: powerlessness, injustice, irresponsibility and vicarious stress (505-506). According to Audre Lorde, "Women[sic] responding to racism means women['s] responding to anger; the anger of exclusion, of unquestioned privilege, of racial distortions, of silence, ill-use, stereotyping, defensiveness, misnaming, betrayal, and co-optation" (124). She asserts in the same essay that anger is a positive emotion that is necessary for growth (Ibid). This assertion goes hand in hand with P. Collins's idea that this anger is useful because it might lead to an action (Collins, 113). Anger becomes the mechanism that motivates all the female characters in Wedding Band, particularly Julia, Herman's mother and his sister.

In Childress's work which deals with dissatisfaction, the heroines reveal how confrontations with others can create "productive conflict that comments on the construction of blackness" (Diggs, 31). Childress is aware of the racial discord of white-black women. She depicts angry and defiant women as a means to illustrate the hostilities that American's history of white racism breeds between white and black women (Jennings, 43). In her Wedding Band, Childress employs anger in her presentation of the frustration the heroine feels about her unfruitful relation with Herman, mainly because of racism.

The modern black Juliet, Julia, is presented in the stage direction as "an attractive brown woman about thirty-five years old" (Wedding Band, 78). The very first words she utters in the play show her defiant nature:

JULIA. (Nervous but determined to present a firm stand.) Oh, my ... Good mornin' ladies. My name is Julia Augustine. I'm not gonna move. (Wedding Band, 78)

She appears in an act of defence from the first morning she lives in the new nighborhood. She is prepared for any expected aggressive attitude from the people she moves to live with This is because of her feeling of injustice. She thinks that they know about her relationship with a white man that is why they want her to leave. She "endures not only the indignity of a socio-politically inscribed legal inferiority but also racial discrimination by a black and white social system that contentiously questions how dark is 'black' and how light is 'white"' (Cashman, 11). She feels entrapped in a black and white world that knows no compromises.

Julia's world rotates around her "illicit" affair with Herman, she is sensitive to her insecure situation (Crowe, 4). She has moved many times from a place to another over the last ten years, trying to escape both black and white judgment of having an affair with a white man. The unjust treatment of the society triggers her fears and causes her to be defiant and angry. Kelly Crowe points out that Julia confronts:

society's laws, people of her own race, white people and her conscience to defend a relationship that in no way can ever exist before the eyes of the ruling class. This never stops Julia though, instead she relocates her entire life so people won't judge or expose the forbidden relationship. (Ibid.)

She complains to other women Mattie, a neighbor and Fanny, a landlady, form her loneliness and her status as an outsider in a society that oppresses her: 
Oh, the things I can tell you 'bout bein' lonesome and shut-out, Always movin' one place to another, lookin' for some peace of mind. I moved out in the country. Pretty but quiet as the graveyard; so lonesome. Then I found this place hid way in the backyard so quiet, didn't see another soul ... And that's why I thought yall wanted to tear my house down this mornin'...' cause you might-a heard 'bout me and Herman.... and some people are ... well, they judge, they can't help judgin' you. (Wedding Band, 91)

Because of her insecurities, she wants to create human bondage with other people to keep her solace. Thus, she tries to maintain bonds with her new neighbors. She is "embarrassed and weary in the first scene of the play. By the end of act one scene one, Julia begins to create bonds with the other women when she reads a letter to Mattie from her husband, October" (Diggs, 37). She feels she has no power to change her situation, and this feeling of powerlessness, according to Thomas, is the main source of anger (505).

Getting to know her affair with Romeo-like, Herman, the women are outraged that a black woman is involved in an affair with a white man. The slave heritage cannot be erased from their racial memory. Lula, another neighbor, is irritated and finds the situation odd. She comments along with Mattie about the "mean" whites:

LULA. A white man is somethin' else. Everybody knows how that low-down slave master sent for a different black woman every night ... for his pleasure. That's why none of us is the same color.

MATTIE. And right now today they're mean, honey. They can't help it; their nose is pinched together so close they can't get enough air. It makes 'em mean. And their mouth is set back in their face so hard and flat ... no roundness, no sweetness, they can't even carry a tune. LULA. I couldn't stand one of 'em to touch me intimate no matter what he'd give me. (Wedding Band, 91-2)

Obviously, such far-fetched romantic unions are condemned to failure, mainly because of the dark legacy of racism and social abjection. The women here cannot view Julia and Herman's liaison as a humane bond that exceeds racial differences. Instead, they consider it as a betrayal for their race and to the long history of persecution the blacks have undergone. Regardless of her neighbors' negative judgment of her white lover, "Julia still yearns to be part of their community" (Diggs, 37). According to her new neighbors, she has to choose between to be a conformist or an outcast.

The enraged and determined African-American heroine, Julia, does not belong to black women who are depicted as submissive, passive, and obedient; she is one of the "poor, dejected heroines who are morally strong, sometimes vulnerable, but resilient" (Brown-Guillory, 99). Julia confronts her white lover's mother, Frieda, in the yard that Julia shares with her neighbors. She, like Childress's other heroines who exercise their right to self-actualization, defies the conventions of the white-dominated society, and redefines her image as a black woman (Jennings, 43). The confrontation between Julia and Herman's mother is full with prejudice familiarity. It dramatizes a battle between two women for social legibility (Diggs, 28). Julia defies Frieda in an attempt to win Herman from the mother and sister he is tied to. She tries her best to silence her anger at the accusations of Herman's mother especially when he asks her to tolerate the actions of his mother and sister. But at the end she does not bear the anger of humiliation and the air of superiority Herman's mother demonstrates. Her anger can no longer be suppressed:

I'm your damn daughter-in-law, you old bitch!. The black thing who bought a hot water bottle to put on your sick, white self when rheumaticism threw flat on your back ... who bought flannel gowns to warm your pale, mean body. He never ran up and down King Street shoppin' for you ... I bought what he took home to you ... the lace crutian in your parlor ... the shirt-waist you wearn' - I made them ... If I wasn't black with all-a Carolina 'ginst me I'd be mistress of your house! Annabelle, you'd be married livin' in Brooklyn, New York ... and I'd be watin' on Frieda ... cookin' your meals. (Wedding Band, 119-120)

She is mature enough to be more defiant than the timid Juliet. She is furious from the fact that it is only the color that has the final word in her relationship with Herman. She realizes that no matter the place she goes to, her blackness will remain the factor that decides her destiny.

The mother is angered by Julia's attempts to pluck Herman from his family and roots and make him a part of a world he does not belong to. She is a typical white woman who has been raised to feel superior. In Sources of Stress and Relief for African American Women, C. F. Collins states that "some white women are raised from birth with the notion that their white, privileged status makes them superior to others" (41). Herman's mother even acts maliciously towards her only son forcing him to leave the woman he loves. She believes that she and her son should not be bound to an inferior race, she addresses Julia by saying 'I'm as high over you as Mount Everest over the sea. White reign supreme,... I'm white, you can't change that" (Wedding Band, 120). According to her, her son is "better off dead in his coffin" than live with the like of Julia (Ibid., 119). She is unable to imagine the horrible consequences of Herman's supposed marriage from Julia: "There's something wrong 'bout mismatched things" (Wedding Band, 117). That is why Herman's mother directs her feeling of anger and disdain towards Julia.

Herman's sister, Annabelle, is another obstacle that stand in the way of Julia's happiness. She is outraged by the idea that her brother is acting foolishly and has no responsibility towards his family. Annabelle arrogantly explains to Julia, "I promised my mother I'd try and talk to you. Now - you look like one-a the nice coloreds ..." (Wedding Band, 109).

From her first appearance on the stage, Annabelle's body language shows her insecurities. In the stage direction, she is described as

... a woman in her thirties. She assumes a slightly mincing air of fashionable delicacy. She might be graceful if she were not ashamed of her size. She is nervous and fearful in this strange atmosphere. The others fall silent as they see her. (Wedding Band, 107) 
She is not satisfied with anything even her looks. In her first encounter, with Julia, Annabelle seems distressed and uneasy for her presence in Julia's place and her brother's relationship with a black woman which she considers as an ugly and unacceptable association.

Annabelle: Dammit, hush. Hush this noise. Sick or not sick, hush! It is ugliness. [To Julia] Let me take care of him. Please leave us alone. (Wedding Band, 109)

Like her mother, Annabelle thinks that her brother is irresponsible and reckless. He is unaware of the mistake he commits when he bonds himself with Julia. She addresses him:

I thought so highly of you ... and here you are in somethin' that's been festerin' for years. [In disbelief] One of the finest women in the world is pinin' her heart out for you, a woman who's pure gold. Everything Celestine does for Mama she's really doin' for you ... to get next to you ... But even a Saint wants some reward. (Wedding Band, 109-10)

Shakespeare's Juliet commit a suicide after her lover's death, but the heroine in Wedding Band survives her Romeo-like Herman, and she becomes a victim of her traumatic memory that intensifies her prejudice against the racial world in which she lives. However, Julia's survival is also a sign of resistance and strength. It reflects her determination to go on living despite her sense of loss and the tragic destiny of her paramor. History repeats itself. Like Romeo and Juliet, Julia and Herman have no flaws of their own to bring about their tragic downfall. It is their society that is responsible for their suffering and tragedy.

\section{REFERENCES}

Audre Lorde. “The Uses of Anger". Women's Studies Quarterly, Vol. 25, No. 1/2, Looking Back, Moving Forward: 25Years of Women's Studies History (Spring - Summer, 1997), pp. 278-285. Web

Barrios, Olga. "African American women in the performing arts". In Mitchell, A., \& Taylor, D. K. in The Cambridge companion to African American women's literature. Cambridge: Cambridge University Press. Beaulieu, E. A. Writing African American women: An encyclopedia of literature by and about women of color. Westport, Conn: Greenwood Press, 2009. Print

Brown-Guillory, E. Their place on the stage: Black women playwrights in America. New York: Praeger,1990. Print.

Cashman, Nicky. "Politics, Passion, Prejudice: Alice Childress's Wedding.
Band: A Love/Hate Story in Black and White." Journal of American Studies 43.3,2009. p. 407-423. Web.

Childress, A. Wedding Band in Wilkerson, M. B. 9 plays by Black women. New York: Mentor,1986. Print.

Collins, C. F. Sources of Stress and Relieffor African American women. Westport, Conn: Praeger, 2003. Print

Collins, P. H. Black Feminist Thought: Knowledge, consciousness, and the politics of empowerment. New York; London: Taylor \& Francis, 2000. Print

Crowe, Kelly. "The Emergence of a New Female Archetype in $20^{\text {th }}$.

Century Drama" August Wilson Blog. https://augustwilsonblog.files.wordpress.com $/ 2017 / 03 /$ the_emergenc of_a new_female_archetype _in_20th_century_drama_by_ kelly_crowe.pdf. Accessed on $21^{\text {st }}$ November, 2017. Web

Diggs, Soyica. "Dialectical dialogues Performing blackness in the drama of Alice Childress" in Kolin Philip C. "Introduction" Kolin, Philip C. Contemporary African American Women Playwrights: A Casebook. London: Routledge, 2012. Print

González-Prendes \& Thomas "Powerlessness and Anger in African American Women: The Intersection of Race and Gender "International Journal of Humanities and Social Science, Vol. 1 No. 2011. 7 p 1-8. Web

Hill, A. D., Barnett, D. Q., \& Hill, A. D. The A to Z of African American theater. Lanham, Md: Scarecrow Press, 2009. E-book Web.

Jennings, "Segregated Sisterhood: Anger, Racism, and Feminism in Alice Childress's Florence and Wedding Band in Marsh-Lockett, C. P. Black women playwrights: Visions on the American stage. New York: Garland Pub, 1999. Web

Osborne, Elizabeth A. "Wedding Band” in Bryer, Jackson R, and Mary C. Hartig. in Bryer, J. R. The Facts on File companion to American drama. New York, NY: Facts On File, 2010. E-book Web

Page, Y. W. Encyclopedia of African American women writers. Westport, Conn: Greenwood Press, 2007. Print

Schipper, Mineke. "Oral Tradition and African Theatre" 123135 in La Tradition Orale Source De La Litterature Contemporaine En Afrique. Dakar: Nouvelles Editions Africaines, 1985. Web

Thomas, S.P. Women's anger, aggression, and violence. Health Care for Women International, 26,2005. 504522. Web 